\title{
Occult hepatitis B infection among individuals belonging to the aboriginal Nicobarese tribe of India
}

\author{
Haimanti Bhattacharya ${ }^{1,2, *}$, Debdutta Bhattacharya ${ }^{1,3, *}$, Subarna Roy ${ }^{1,3}$, Attayur Purushothaman \\ Sugunan $^{1}$ \\ ${ }^{1}$ Regional Medical Research Centre (Indian Council of Medical Research), Port Blair, Andaman and Nicobar \\ Islands, India \\ ${ }^{2}$ Dr. Prabhakar Kore Basic Science Research Centre, KLE University, Belgaum, India \\ ${ }^{3}$ Regional Medical Research Centre (Indian Council of Medical Research), Opp. KLES Hospital, Nehru Nagar, \\ Belgaum, India
}

*Authors contributed equally to this work.

\begin{abstract}
Introduction: The long-lasting persistence of hepatitis B virus (HBV) genomes in the liver (with or without detectable HBV DNA) of individuals with negative for HBV surface antigen (HBsAg) is termed occult HBV infection (OBI). The present study is a part of the follow up on efficacy of vaccination, 10 years post inception, and was designed to understand the prevalence of Occult Hepatitis B infection (OBI) among the aboriginal Nicobarese tribal community.

Methodology: A total of 612 serum samples were collected and tested for various markers including HBsAg, Anti-HBs, Anti-HBc and HBV DNA. Part of S gene of the extracted HBV DNA was amplified by nested PCR. The amplified products were then subjected to sequencing. Genotyping was performed on the basis of phylogenetic relationship along with representative reference sequences from different sub genotypes.

Results: The study revealed OBI in $11.1 \%$ of the people belonging to the Nicobarese tribe. Phylogenetic analysis showed only one genotype, HBV/D circulating among the Nicobarese population with ayw3 was the major serotype detected. Single or multiple amino acids substitutions were found in 5 of 34 samples (14.7\%) which includes I110T, P120T, P/T127I, A128P, M133L and G159V.

Conclusions: The detection of OBI among these aboriginal tribes is of great concern and stresses the need for the continuous surveillance as it may contribute to the progression of liver disease to a more advanced stage.
\end{abstract}

Key words: HBV; occult; Nicobarese; primitive; HCC; cirrhosis.

J Infect Dev Ctries 2014; 8(12):1630-1635. doi:10.3855/jidc.4350

(Received 24 October 2013 - Accepted 16 April 2014)

Copyright (C) 2014 Bhattacharya et al. This is an open-access article distributed under the Creative Commons Attribution License, which permits unrestricted use, distribution, and reproduction in any medium, provided the original work is properly cited.

\section{Introduction}

Hepatitis B is one of the most common infectious diseases with approximately 400 million chronic carriers around the world [1], of which more than 40 million are from India [2]. Occult HBV infection (OBI) is defined as the presence of circulating HBV DNA in the absence of serologically detectable hepatitis B surface antigen (HBsAg negative) [3-5]. The HBV DNA may be present in patients with serological markers of previous infection (anti-HBc and/or anti-HBs positive) or in patients without serological markers (anti-HBc and/or anti-HBs negative). Serological tests are useful in identifying different antigens and antibodies in various stages of infection. Anti-HBc antibodies appear in the acute phase of infection and persist for an indefinite time after virus clearance. The presence of antibodies against HBsAg (anti-HBs) is a marker of recovery and immunity. Anti-HBc coexisting with anti-HBs usually indicates a previous HBV infection, and when it coexists with HBsAg, a current infection [6]. The prevalence of OBI is variable depending on the level of endemicity, assays used, and the populations studied [7]. The Andaman and Nicobar Islands, a union territory of India, is situated in the Bay of Bengal and is home to six aboriginal tribes, constituting about $10 \%$ of the islands' population. Serological studies carried out earlier among the four accessible tribes revealed that HBV is widely prevalent among them. The Nicobarese, the largest 
tribal group, had a prevalence of $23.3 \%$ [8]. Considering the high endemicity of HBV infection among the tribes, a pilot project of mass hepatitis B vaccination was initiated in 2000, in two of the 12 villages of Car Nicobar Island inhabited exclusively by the Nicobarese tribe [9]. The present study was conducted 10 years after the implementation of this vaccination program and was designed to understand the prevalence of OBI among this tribal community due to the high endemicity of hepatitis B.

\section{Methodology}

A cross-sectional study $(\mathrm{n}=612)$ was conducted between September 2010 and July 2011, in which serum samples were collected from individuals living in the two villages of Car Nicobar Islands covered under the vaccination program implemented 10 years ago. The study was cleared by institutional ethical committee.

$\mathrm{HBsAg}$, anti-HBs, and anti-HBc were tested by commercial enzyme-linked immunosorbent assay (ELISA) (General Biologicals Corporation, Hsin Chu Science Park, Taiwan).

All the anti-HBc positive samples were tested twice and only those that yielded repeated positive results were considered to be anti-HBc positive.

HBV DNA was isolated from $200 \mu \mathrm{L}$ serum samples using phenol/isoamyl alcohol/chloroform after incubation with proteinase K [10]. Part of the S gene of the extracted HBV DNA was amplified by nested polymerase chain reaction (PCR) following standard protocol [10]. Primers used for first-round
PCR were 5'-ACCCCTGCTCGTGTTACAGGC-3' (sense, nt 184-204) and 5'AAAGCCAGACAGTGGGGGAAA-3' (antisense, nt 731-711). For second-round PCR, $1 \mu \mathrm{L}$ of the firstround PCR product was subjected to PCR amplification of 25 cycles using primers 5'GACTCGTGGTGGACTTCTCTC-3' (sense, nt 251271) and 5'-TAAACTGAGCCAGGAGAAACG-3' (antisense, nt 679-659) to obtain a product of amplicon size $429 \mathrm{bp}$. The concentration of primers and PCR reactants was identical to first-round PCR. Guidelines for avoiding false positive results [11] were followed strictly. The amplified products were then subjected to sequencing in Genetic Analyzer (Applied Biosystems, Foster City, USA). Each amplicon was sequenced in both directions. All the nucleotide sequence data were derived from two independent readings. The forward and reverse sequences collected from the sequencer were checked and manually edited in the electro-pherograms using the SeqScape version 2.5 (Applied Biosystems) and MEGA5 software [12]. Genotyping was performed on the basis of phylogenetic relationship, taking 345 base pair sequences along with representative reference sequences from different sub genotypes as described earlier for hepatitis B virus [13,14]. Phylogenetic grouping using a bootstrap neighbour-joining (NJ) analysis with 1,000 replications was performed using the $\mathrm{S}$ gene sequence of $\mathrm{HBV}$ isolated from Nicobarese tribes and that of other representative sequences submitted in the NCBI database.

Table 1. Overall demographic, serological, and virological characteristics of anti-HBs $(+) /$ anti-HBc $(+)$ group among the individuals belonging to the Nicobarese tribe

\begin{tabular}{ll}
\hline Features & $\begin{array}{l}\text { Total } \\
\text { Vaccinated }\end{array}$ \\
\hline HBsAg (-ve) & 558 \\
Age in years (mean \pm SD) & $41.2 \pm 1.1$ \\
Male/Female & $227 / 331$ \\
HBV DNA positive (\%) & $62 / 612(10.1 \%)$ \\
Anti-HBc+anti-HBs (+ve) (\%) & $22 / 62(35.5 \%)$ \\
Anti-HBc only (+ve) (\%) & $18 / 62(29.0 \%)$ \\
Anti-HBs only (\%) & $12 / 62(19.4 \%)$ \\
Anti-HBc+anti-HBs (-ve) (\%) & $10 / 62(16.1 \%)$ \\
Positive for sequencing & 47 \\
HBV genotype by sequencing (\%) & \\
D & $47(100 \%)$ \\
Serotype & \\
ayw3 & 38 \\
ayw2 & 8 \\
ND & 1 \\
\hline
\end{tabular}


Table 2. Details of the patients belonging to the Nicobarese tribe with OBI infection

\begin{tabular}{|c|c|c|c|c|c|}
\hline \multirow{2}{*}{ SI No. } & \multirow{2}{*}{ Sample No. } & \multirow{2}{*}{ Age (in years)/sex } & \multicolumn{2}{|c|}{ SEROLOGY } & \multirow{2}{*}{ Amino acid change (100-160aa) } \\
\hline & & & Anti-HBs (mIU/mL) & Anti-HBc & \\
\hline 1 & LT0192 & $17 / \mathrm{F}$ & 122 & $\mathrm{~N}$ & - \\
\hline 2 & LT0248 & $48 / \mathrm{F}$ & 391 & $\mathrm{~N}$ & - \\
\hline 3 & LT0738 & $20 / \mathrm{M}$ & 865.3 & $\mathrm{P}$ & - \\
\hline 4 & LT0742 & $56 / \mathrm{M}$ & 69.5 & $\mathrm{P}$ & - \\
\hline 5 & LT0749 & $21 / \mathrm{F}$ & 1055.2 & $\mathrm{~N}$ & - \\
\hline 6 & LT0753 & $40 / \mathrm{F}$ & 765.8 & $\mathrm{~N}$ & - \\
\hline 7 & LT0759 & $16 / \mathrm{M}$ & 418.6 & $\mathrm{~N}$ & - \\
\hline 8 & LT0760 & $36 / \mathrm{F}$ & 747.7 & $\mathrm{P}$ & - \\
\hline 9 & LT0761 & $38 / \mathrm{F}$ & 700.8 & $\mathrm{P}$ & - \\
\hline 10 & LT0762 & $13 / \mathrm{M}$ & 1091.5 & $\mathrm{~N}$ & - \\
\hline 11 & LT0199 & $18 / \mathrm{M}$ & 5 & $\mathrm{~N}$ & - \\
\hline 12 & LT0256 & $72 / \mathrm{F}$ & 6 & $\mathrm{P}$ & - \\
\hline 13 & LT0441 & $32 / \mathrm{F}$ & 4.7 & $\mathrm{P}$ & - \\
\hline 14 & LT0132 & $28 / \mathrm{F}$ & 152 & $\mathrm{~N}$ & - \\
\hline 15 & LT0181 & $39 / \mathrm{F}$ & 283 & $\mathrm{P}$ & - \\
\hline 16 & LT0184 & $20 / \mathrm{F}$ & 44 & $\mathrm{~N}$ & - \\
\hline 17 & LT0187 & $58 / \mathrm{M}$ & 16 & $\mathrm{~N}$ & - \\
\hline 18 & LT0195 & $59 / \mathrm{F}$ & 214 & $\mathrm{P}$ & - \\
\hline 19 & LT0197 & $56 / \mathrm{F}$ & 13 & $\mathrm{P}$ & - \\
\hline 20 & LT0202 & $65 / \mathrm{M}$ & 37 & $\mathrm{P}$ & - \\
\hline 21 & LT0208 & $32 / \mathrm{F}$ & 264 & $\mathrm{P}$ & - \\
\hline 22 & LT0209 & $35 / \mathrm{F}$ & 40 & $\mathrm{P}$ & - \\
\hline 23 & LT0214 & $60 / \mathrm{M}$ & 11 & $\mathrm{P}$ & - \\
\hline 24 & LT0223 & $49 / \mathrm{F}$ & 45 & $\mathrm{P}$ & - \\
\hline 25 & LT0258 & $39 / \mathrm{F}$ & 64 & $\mathrm{P}$ & - \\
\hline 26 & LT0260 & $39 / \mathrm{F}$ & 13 & $\mathrm{P}$ & - \\
\hline 27 & LT0269 & $52 / \mathrm{M}$ & 317 & $\mathrm{P}$ & - \\
\hline 28 & LT0291 & $38 / \mathrm{M}$ & 24 & $\mathrm{P}$ & - \\
\hline 29 & LT0293 & $44 / F$ & 10 & $\mathrm{P}$ & - \\
\hline 30 & LT0347 & $35 / \mathrm{M}$ & 15.3 & $\mathrm{P}$ & - \\
\hline 31 & LT0355 & $52 / \mathrm{M}$ & 58 & $\mathrm{~N}$ & - \\
\hline 32 & LT0373 & $23 / \mathrm{F}$ & 440.4 & $\mathrm{P}$ & - \\
\hline 33 & LT0381 & $24 / F$ & 182.3 & $\mathrm{P}$ & $\mathrm{A} 128 \mathrm{P}$ \\
\hline 34 & LT0411 & $45 / \mathrm{M}$ & 31.1 & $\mathrm{~N}$ & - \\
\hline 35 & LT0474 & $29 / \mathrm{M}$ & 59.9 & $\mathrm{P}$ & - \\
\hline 36 & LT0609 & $6 / F$ & 446.5 & $\mathrm{~N}$ & - \\
\hline 37 & LT0610 & $39 / \mathrm{M}$ & 479.8 & $\mathrm{P}$ & - \\
\hline 38 & LT0069 & $48 / \mathrm{F}$ & 9 & $\mathrm{P}$ & - \\
\hline 39 & LT0185 & $65 / \mathrm{F}$ & 3 & $\mathrm{~N}$ & - \\
\hline 40 & LT0194 & $71 / \mathrm{M}$ & 4 & $\mathrm{P}$ & - \\
\hline 41 & LT0203 & $50 / \mathrm{F}$ & 8 & $\mathrm{P}$ & - \\
\hline 42 & LT0206 & $11 / \mathrm{F}$ & 5 & $\mathrm{~N}$ & - \\
\hline 43 & LT0220 & $12 / \mathrm{F}$ & 4 & $\mathrm{~N}$ & - \\
\hline 44 & LT0263 & $26 / \mathrm{F}$ & 3 & $\mathrm{P}$ & - \\
\hline 45 & LT0265 & $35 / F$ & 6 & $\mathrm{P}$ & P120T \\
\hline 46 & LT0294 & $45 / \mathrm{M}$ & 9 & $\mathrm{P}$ & I110T, G159V \\
\hline 47 & LT0297 & $49 / \mathrm{F}$ & 3 & $\mathrm{P}$ & $\mathrm{P} / \mathrm{T} 127 \mathrm{I}$ \\
\hline 48 & LT0312 & $52 / \mathrm{F}$ & 5 & $\mathrm{P}$ & M133L \\
\hline 49 & LT0437 & $45 / \mathrm{F}$ & 4.8 & $\mathrm{P}$ & - \\
\hline 50 & LT0438 & $55 / \mathrm{F}$ & 4.2 & $\mathrm{P}$ & - \\
\hline 51 & LT0460 & $63 / \mathrm{F}$ & 0.2 & $\mathrm{P}$ & - \\
\hline 52 & LT0212 & $22 / \mathrm{F}$ & 8 & $\mathrm{P}$ & - \\
\hline 53 & LT0224 & $26 / \mathrm{F}$ & 4 & $\mathrm{~N}$ & - \\
\hline 54 & LT0225 & $35 / \mathrm{F}$ & 5 & $\mathrm{~N}$ & - \\
\hline 55 & LT0246 & $60 / \mathrm{F}$ & 4 & $\mathrm{P}$ & - \\
\hline 56 & LT0331 & $14 / \mathrm{F}$ & 3.2 & $\mathrm{~N}$ & - \\
\hline 57 & LT0582 & $7 / \mathrm{M}$ & 1.9 & $\mathrm{~N}$ & - \\
\hline 58 & LT0592 & $25 / F$ & 0.9 & $\mathrm{~N}$ & - \\
\hline 59 & LT0595 & $60 / \mathrm{F}$ & 4.9 & $\mathrm{P}$ & - \\
\hline 60 & LT0596 & $19 / \mathrm{F}$ & 1.3 & $\mathrm{~N}$ & - \\
\hline 61 & LT0633 & $53 / \mathrm{F}$ & 2 & $\mathrm{P}$ & - \\
\hline 62 & LT0647 & $67 / \mathrm{M}$ & 4.3 & $\mathrm{P}$ & - \\
\hline
\end{tabular}


Representative sequences belonging to each genotypes of hepatitis $\mathrm{B}$ (i.e., $\mathrm{A}, \mathrm{B}, \mathrm{C}, \mathrm{D}, \mathrm{E}, \mathrm{F}$, and $\mathrm{H}$ ) were extracted from the NCBI database and used in the phylogenetic analysis. The sequence of woolly monkey HBV was used as an outgroup to root the phylogenetic tree. Mutations present, if any, in the amino acids of the hepatitis B isolated from Nicobarese tribe members were detected using MEGA5 software by comparing them with other sequences submitted in the NCBI GeneBank. The representative sequences of each genotype are indicated in the phylogeny with their accession number along with their genotype.

\section{Results}

The demographic, serological, and virological characteristics are shown in Table 1.

Out of 612 serum samples collected, 558 (91.2\%) were negative for $\mathrm{HBsAg}$, which included samples from 227 males and 331 females (mean age $41.2 \pm$ 1.1).

Among these HBsAg-negative samples, 62 were positive for HBV DNA by PCR, giving a prevalence of $10.1 \%(62 / 612)$ for occult hepatitis. Among these 62 cases of occult hepatitis, $52(83.9 \%)$ were positive for either anti-HBs, anti-HBsAg, or both, indicating these patients probably had long-standing infections and low viral loads with undetectable levels of HBsAg. Twenty-two (35.5\%) of the occult hepatitis B cases were positive for both anti-HBc and antiHBsAg, while 18 (29.0\%) were positive for only anti$\mathrm{HBc}$, and $12(19.4 \%)$ were positive for only antiHBsAg. Ten $(16.1 \%)$ of the 62 cases of occult hepatitis were negative for all serological markers of hepatitis B that were screened for (Table 1).

Out of these 62 samples positive for HBV DNA, bidirectional sequencing of a partial $\mathrm{S}$ gene was successfully achieved for 47 samples. Phylogenetic analysis showed only one genotype, HBV/D, circulating among the vaccinated population (Figure 1).

Out of these $47 \mathrm{HBV}$ isolates with $\mathrm{D}$ genotype, ayw3 was the major $(38 / 47,80.9 \%)$ serotype, and 8 $(8 / 47,17 \%)$ isolates belonged to ayw2 serotype (Table 1).

Serotype could not be detected for one isolate, LT0297, due to an amino acid change at the serotype determining position (Table 2). Among HBsAgnegative non-vaccinated samples, single or multiple amino acids substitutions were found in 5 of 47 samples (10.6\%). The amino acid substitutions found
Figure 1. Phylogenetic analysis of the partial $\mathrm{S}$ gene showing the genotype of the HBV virus from OBI cases (LT)

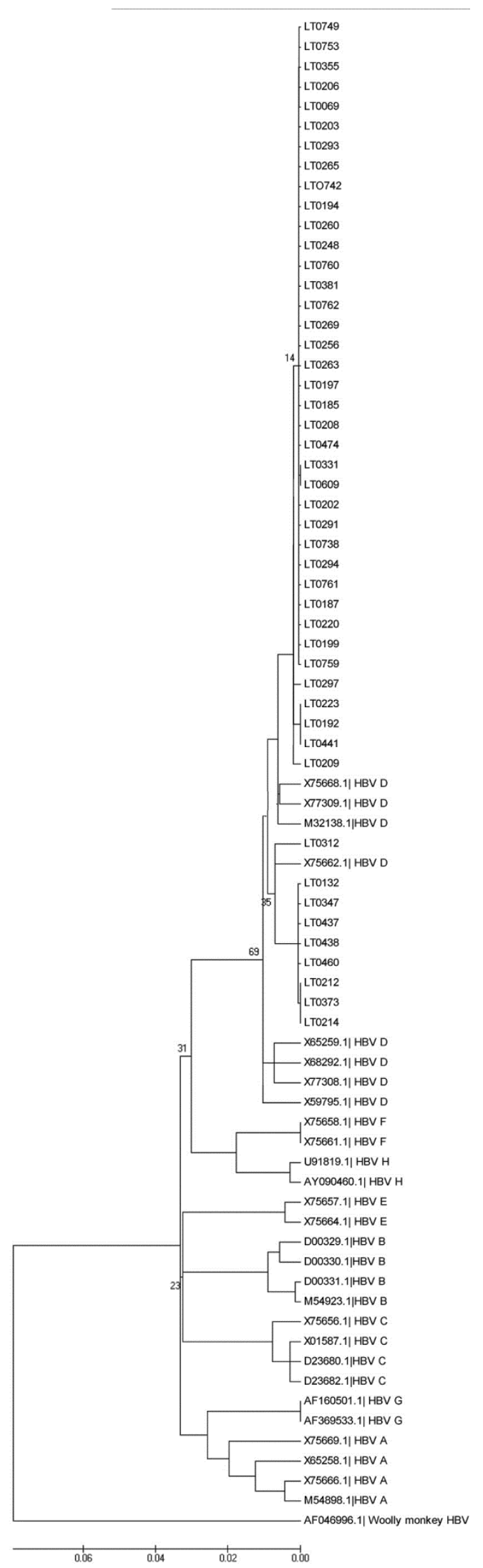


within the S-gene region were I110T, P120T, P/T127I, A128P, M133L, and G159V (Table 2).

The nucleotide sequences determined in this study have been submitted to the GenBank database and assigned accession numbers KC433959, KC433966 and KC433962-64.

\section{Discussion}

Several reports exist demonstrating the persistence of HBV DNA in different populations or individuals carrying either anti-HBs or anti-HBc only, particularly in blood donors $[15,16]$. The present study revealed OBI in $10.1 \%$ of individuals belonging to the Nicobarese tribe. Varying prevalence of anti-HBc, a marker for exposure to $\mathrm{HBV}$ infection, has been reported from different parts of India, ranging between $8 \%$ and $18 \%$ [5]. Prevalence of occult HBV infection was also high among the anti-HBc positive individuals belonging to the vaccinated and non-vaccinated cohorts from the present study; $64.5 \%$ (40/62) of antiHBc-positive cases were HBV DNA positive. According to an earlier report [17], about $20 \%$ of OBI sera are negative for all serological markers of HBV infection except HBV DNA, 50\% are positive for anti$\mathrm{HBc}$ ( \pm anti-HBs), and $35 \%$ are positive for anti-HBs ( \pm anti-HBc).

Different clinical contexts are reported behind the mechanism of OBI; these include undetectable HBsAg at the tail end of chronic carriage during the long term non-replicative phase, the occurrence of escape mutants interfering with HBsAg synthesis, coinfection with delta hepatitis virus (HDV), and, commonly in endemic areas, chronic carriage stage with HBsAg too low to be detected and recognized by the presence of anti-HBc as the only serological marker (referred to as "anti-HBc alone" or "isolated anti-HBc") [4].

The frequency of occult HBV infection varies considerably from different parts of the world according to the prevalence of HBV in the population [5]. Studies from other parts of India reported occult $\mathrm{HBV}$ infection ranging from $21 \%$ in Kolkata (eastern India), $20.87 \%$ in New Delhi (northern India) to $0 \%$ in Chandigarh (north-western India) [18-20].

The prevalence of anti-HBs was found to be higher than prevalence of HBsAg among the Nicobarese before vaccination, and half of the HBsAg- and antiHBs-negative people were positive for anti-HBc (54\%) [9]. Earlier findings suggest that recovery from acute hepatitis B virus infection may not result in complete virus elimination; rather, the immune system keeps the virus at a very low level, leading to occult hepatitis B infection [20].

HBV genotype is also an important factor influencing the frequency of occult HBV. Occult HBV during the non-replicative phase has been found to be more frequent in areas where genotypes $\mathrm{A}, \mathrm{D}$, and $\mathrm{E}$ are prevalent rather than genotypes B and C $[4,21]$. Our report is in accordance with an earlier report [5] from India that revealed HBV/D as the prevalent genotype among OBI cases.

The P120T substitution reported in our study was earlier found to be linked with chronic hepatitis and liver cirrhosis patients [22], to possibly cause problems with diagnostic assays, and to also possibly cause vaccine escape and poor response to HBIG therapy [23]. The mutations (I110T, A128P, G159V, and M133L) observed here were reported earlier to be associated with diagnostic or immune escape and impaired virion secretion [24].

There is increasing evidence that $\mathrm{OBI}$ is associated with chronic liver disease and HCV progression and that it interferes with treatment response $[5,25,26]$ in addition to being a source of transmission of HBV. The implications of occult HBV infection involve different clinical aspects, which include presenting potential risks of HBV transmission through blood transfusion, hemodialysis, and organ transplantation; causing cryptogenic liver disease; and contributing to acute exacerbation of chronic hepatitis B or even fulminant hepatitis. It is also associated with development of hepatocellular carcinoma and may affect disease progression and treatment response of chronic hepatitis B and C [27].

\section{Conclusions}

The detection of occult hepatitis B among these aboriginal tribes is of great concern. The study stresses the need for the continuous surveillance of patients with OBI, as it may contribute to the progression of liver disease to a more advanced stage. The present study indicates that routinely used serological markers of HBV infection do not rule out occult and ongoing hepatitis B virus infections, and emphasizes application of molecular methods for the detection of occult HBV infection. Our study advocates inclusion of HBV DNA testing along with anti-HBc test for screening of HBV infection as a routine practice.

\section{Acknowledgements}

The authors are thankful to the Tribal Council and the village captains of Tamaloo and Big Lapathy, Car Nicobar Islands for their extensive support and cooperation. The 
authors are also thankful to Lady Tata Memorial Trust for providing Junior Scholarship to Haimanti Bhattacharjee. The authors are thankful to Mr. D R Guruprasad and Ms. Sylvia Frank for providing field assistance. The study was supported by the intramural grants from the Indian Council of Medical Research. No external funds were received for conducting the study.

\section{References}

1. Lai CL, Yuen MF (2008) Chronic Hepatitis B - New Goals, New Treatment. N Eng J Med 359: 2488-2491.

2. Tandon BN, Acharya SK, Tandon A (1996) Epidemiology of hepatitis B virus infection in India. Gut 38: S56-S59.

3. Chaudhuri V, Tayal R, Nayak B, Acharya SK, Panda SK (2004) Occult Hepatitis B Virus Infection in Chronic Liver Disease: Full-Length Genome and Analysis of Mutant Surface Promoter. Gastroenterol 127: 1356-1371.

4. Allain JP (2004) Occult hepatitis B virus infection. Transfus Clin Biol 11: 18-25.

5. Panigrahi R, Biswas A, Datta S, Banerjee A, Chandra PK, Mahapatra PK, Patnaik B, Chakrabarti S, Chakravarty R (2010) Anti-hepatitis B core antigen testing with detection and characterization of occult hepatitis $\mathrm{B}$ virus by an in-house nucleic acid testing among blood donors in Behrampur, Ganjam, Orissa in southeastern India: implications for transfusion. Virol J 7: 204.

6. Gitlin N (1997) Hepatitis B: diagnosis, prevention, and treatment. Clin Chem 43: 1500-1506.

7. Candotti D, Allain JP (2009) Transfusion-transmitted hepatitis B virus infection. J Hepatol 51: 798-809.

8. Murhekar MV, Murhekar KM, Das D, Arankalle VA, Sehgal SC (2000) Prevalence of hepatitis B infection among the primitive tribes of Andaman and Nicobar islands. Ind J Med Res 111: 199-203.

9. Murhekar MV, Murhekar KM, Arankalle VA, Sehgal SC (2002) Immune response to an indigenously developed hepatitis B (Shanvac-B) vaccine in a tribal community of India. Vaccine 20: 3431-3435.

10. Arankalle VA, Murhekar KM, Gandhe SS, Murhekar MV, Ramdasi AY, Padbidri VS, Sehgal SC (2003) Hepatitis B virus: predominance of genotype $\mathrm{D}$ in primitive tribes of the Andaman and Nicobar islands, India (1989-1999). J Gen Virol 84: 1915-20.

11. Kwok S, Higuchi R. (1989) Avoiding false positives with PCR. Nature 339: 237-238.

12. Tamura K, Peterson D, Peterson N, Stecher G, Nei M, Kumar S (2011) MEGA5: Molecular evolutionary genetics analysis using maximum likelihood, evolutionary distance, and maximum parsimony methods. Mol Biol Evol 28: 2731-2739.

13. Norder H, Couroucé AM, Coursaget P, Echevarria JM, Lee $\mathrm{SD}$, Mushahwar IK, Robertson BH, Locarnini S, Magnius LO (2004) Genetic diversity of hepatitis B virus strains derived worldwide: genotypes, subgenotypes, and HBsAg subtypes. Intervirol 47: 289-309.

14. Banerjee A, Kurbanov F, Datta S, Chandra PK, Tanaka Y, Mizokami M, Chakravarty R (2006) Phylogenetic relatedness and genetic diversity of hepatitis $\mathrm{B}$ virus isolates in eastern India. J Med Virol 78: 1164-1174.

15. Silvaa CMD, Costi C, Costa C, Michelon C, Oravec R, Ramos AB, Niel C, Rossetti ML (2005) Low rate of occult hepatitis $\mathrm{B}$ virus infection among anti-HBc positive blood donors living in a low prevalence region in Brazil. J Infect 51: 24-29.

16. Niederhauser C, Weingand T, Candotti D, Maier A, Tinguely C, Wuillemin WA, Gowland P, Allain JP, Stolz M (2010) Fatal outcome of a hepatitis B virus transfusion-transmitted infection. Vox Sang 98: 504-507.

17. Torbenson M, Thomas DL (2002) Occult hepatitis B. Lancet Infect Dis 2: 479-486.

18. Duseja A, Sharma S, Subramanian PG, Agnihotri SK, Chakraborti A, Chawla Y (2003) Occult hepatitis B virus (HBV) infection in healthy blood donors. Indian J Pathol Microbiol 46: 690-692.

19. Bhattacharya P, Chandra PK, Datta S, Banerjee A, Chakraborty S, Rajendran K, Basu SK, Bhattacharya SK, Chakravarty R (2007) Significant increase in HIV, HBV, $\mathrm{HCV}$ and syphilis infections among blood donors in West Bengal, Eastern India 2004-2005: exploratory screening reveals high frequency of occult $\mathrm{HBV}$ infection. World J Gastroenterol 13: 3730-3733.

20. Dhawan HK, Marwaha N, Sharma RR, Chawla Y, Thakral B, Saluja K, Sharma SK, Thakur MK, Jain A (2008) Anti-HBc screening in Indian blood donors: Still an unresolved issue. World J Gastroenterol 14: 5327-5330.

21. Chu CM, Hung SJ, Lin J, Tai DI, Liaw YF (2004) Natural history of hepatitis B e antigen to antibody seroconversion in patients with normal serum aminotransferase levels. Am J Med 116: 829-34.

22. Malik A, Singhal DK, Albanyan A, Husain SA, Kar P (2012) Hepatitis B Virus Gene Mutations in Liver Diseases: A Report from New Delhi. PLoS ONE 7: e39028.

23. Bartholomeusz A, Locarnini S (2006) Hepatitis B virus mutations associated with antiviral therapy. J Med Virol 78: 52-55.

24. Ito K, Qin Y, Guarnieri M, Garcia T, Kwei K, Mizokami M, Zhang J, Li J, Wands JR, Tong S (2010) Impairment of Hepatitis B Virus Virion Secretion by Single-Amino-Acid Substitutions in the Small Envelope Protein and Rescue by a Novel Glycosylation Site. J Virol 84: 12850-12861.

25. Levast M, Larrat S, Thelu MA, Nicod S, Plages A, Cheveau A, Zarski JP, Seigneurin JM, Morand P, Leroy V (2010) Prevalence and impact of occult hepatitis B infection in chronic hepatitis $\mathrm{C}$ patients treated with pegylated interferon and ribavirin. J Med Virol 82: 747-754.

26. Pollicino T, Squadrito G, Cerenzia G, Cacciola I, Raffa G, Craxi A, Farinati F, Missale G, Smedile A, Tiribelli C, Villa E, Raimondo G (2004) Hepatitis B virus maintains its prooncogenic properties in the case of occult HBV infection. Gastroenterol 126: 102-110.

27. Hu KQ (2002) Occult hepatitis B virus infection and its clinical implications. J Viral Hepat 9: 243-257.

\section{Corresponding author}

Dr. A. P. Sugunan, Scientist E/ Deputy Director

Regional Medical Research Centre (ICMR)

Post Bag No.13, Port Blair 744101

Andaman \& Nicobar Islands, India

Phone: +913142 251158; +913142251164

Fax: +91 3142251163

Email: sugunanap@icmr.org.in; pblicmr@sancharnet.in

Conflict of interests: No conflict of interests is declared. 